Article

\title{
Analysing Ecosystem User Perceptions of the Governance Interactions Surrounding a Brazilian Near Shore Coral Reef
}

\author{
Marion Glaser ${ }^{1, *}$, Philipp Gorris ${ }^{1,2}$ (D) , Beatrice Padovani Ferreira ${ }^{3}$ and Annette Breckwoldt ${ }^{1,4}$ (i) \\ 1 Leibniz Centre for Tropical Marine Research (ZMT), 28359 Bremen, Germany \\ 2 Institute of Environmental Systems Research (IUSF), Osnabrueck University (UOS), \\ 49076 Osnabrueck, Germany; philipp.gorris@uni-osnabrueck.de \\ 3 Federal University of Pernambuco (UFPE), Oceanography Department, 50740-550 Recife, Brazil; \\ beatrice@ufpe.br \\ 4 Alfred Wegener Institute Helmholtz Center for Polar and Marine Research (AWI), \\ 27570 Bremerhaven, Germany; annette.breckwoldt@awi.de \\ * Correspondence: marion.glaser@leibniz-zmt.de; Tel.: +49-421-23800-66
}

Received: 27 February 2018; Accepted: 2 May 2018; Published: 7 May 2018

check for updates

\begin{abstract}
This study focuses on understanding stakeholder perceptions in environmental governance and management. Based on an application of the net-mapping method as the main approach for a comparative analysis of local ecosystem users' perceptions, this research elucidates subjective local realities of fishers and tourism operators in two study sites of the governance system of a marine protected area in Northeast Brazil. The findings showed that fishers and tourism operators see themselves as part of specific webs of social relations with associated power asymmetries. The perceived governance interaction networks varied between stakeholder groups, since they see reef governance in relation to their own interests and vulnerabilities. These variations in perception set the scene for different actions. The results of this comparative study show that where ecosystem users perceived the environmental rule system to be equitable and legitimate, its implementation was enhanced, where they did not, it was fraught with difficulties. This points to the potential for applying a systematic approach for differentiating perceptions, and their change over time, as behavioural drivers to strengthen future sustainability research. The article concludes with reflections on net-mapping as a tool for analysing perceptions on environmental governance.
\end{abstract}

Keywords: social network analysis; net-map; coral coast environmental protection area; marine protected area; fishery

\section{Introduction}

Human-nature dynamics in marine territories are shaped by social relations between multiple individual and institutional actors [1]. In a complex system of interrelated social networks, marine governance generates values, policies, laws, and institutions [2]. Distinct ecosystem user groups engage in a complex web of social interactions with each other and with other stakeholders from business, government, and civil society [3,4]. These interactions often entail power and territoriality issues which affect decision-making, human behaviour, and social-environmental successes and failures [2,5,6]. Improved understanding of how ecosystem users are embedded in the complex web of social relations which constitute de facto governance is needed to navigate human-nature interactions more effectively towards sustainable use [7-9].

Coastal reefs in Brazil have high ecological, economic, and social importance [10,11], for fisheries [12] and for tourism [13], and have been impacted by humanity at least since colonial 
times. More recently, population growth in coastal zones, large-scale tourism, coastal construction, uncontrolled industrial development at the land-sea interface including drilling for oil and gas, the expansion of modernized inshore fisheries, and large-scale fishing fleets have put increasing pressure on reefs [14]. Governance must respond to the shifting social and ecological variables that are affecting the health of coral reef ecosystems [15]. Marine Protected Areas (MPAs) are perceived as an important instrument to include coral reef ecosystems in an integrated coastal and marine management approach [6,16-18]. The advantages of effective implementation of MPAs are diverse but generally include ecological and social benefits $[19,20]$. However, merely legally establishing MPAs does by no means ensure improved sustainable resource use and the achievement of marine conservation objectives [21]. Rather, research shows that failures (i.e., paper parks) far outnumber successful MPA implementation around the globe, and this is attributed to governance shortcomings [16,22]. A better understanding of how ecosystem users perceive the governance system they are embedded in offers a promising avenue to improve the implementation of socially just and ecologically beneficial coastal and marine governance [23].

This paper focuses on the potential implications of the differences in the perceptions of ecosystem users of the complex web of social networks related to the governance of a Brazilian MPA. Environmental governance and management hinge upon human and institutional actors, their interests and powers, and on how they affect each other within the respective interactional structures. Environmental governance and management therefore need to deal with ideas and perceptions that guide human behaviour at multiple levels. Research is emerging on the important role of perceptions for human behaviour towards nature in general, and for natural resource management and conservation efforts specifically [23-30]. This study asks two questions: (i) how do the different ecosystem user types perceive the actors in the coral reef governance system they are embedded in, and what are the relations between these actors that affect reef governance?; and (ii) can differences in how stakeholders perceive the environmental (i.e., reef) governance network help explain differences in their behaviour? Following Beyerl et al. [29] (p. 4), perception is understood as " (.. ) the subjective way people experience, think about and understand someone or something." This inductive research uses a mixed method approach combining the net-mapping method [31] with other qualitative research methods for comparatively analysing the subjective local realities of fishers and tourism operators of the governance system of a marine reef environment in two neighbouring areas off Northeastern Brazil. The results elucidate how stakeholder perceptions differ between different ecosystem user types and between places, and how they are linked to behavioural outcomes. The article concludes by illuminating points of leverage for improved governance and offering reflections on net-mapping as a tool for analysing perceptions on environmental governance.

\section{The Study Area}

\subsection{The Coral Coast, Northeastern Brazil}

The Coral Coast, located in Northeastern Brazil, has one of the highest coastal population densities in the country, mainly due to large coastal cities [12]. Along the Pernambuco and Alagoas state coasts, the reefs located in the south of Pernambuco and in the north of Alagoas states (Figure 1) are less impacted due to the distance from the large urban centres [12]. This $150 \mathrm{~km}$ stretch of coast is interconnected, highly diverse, and productive, with remnants of Atlantic rain forest, mangroves, sandbanks, estuaries, seagrass beds, and coral reefs [10]. Reefs with up to three lines parallel to the coast with tops exposed at low tide characterize the coral formations.

Fishery and agriculture have been the main traditional sources of income. More recently, tourism (both international and interstate) has been gaining momentum [32] as the area features a tremendous tourism potential with its year-round warm climate, cultural diversity, and attractive beaches [13]. While tourism may hold strong potential for reducing human impact on coral reefs [33], poor environmental management may also lead to severe negative consequences of tourism for marine 
ecosystems [34,35]. Parts of the local population in the area still also rely on fishing as an important source of income. In the northeast of Brazil, approximately $80 \%$ of the fishing industry relies on fishery products that are associated with coral reefs [12]. In the coral coast area, commercial fishing operates across the platform to the continental slope, and the depletion of fish stocks has also had strong negative impacts on the flora and fauna associated with coral reefs [36].

Our study region is part of the Coral Coast Environmental Protection Area (CC-EPA; the local acronym is APACC), an MPA established under national legislation. Created by federal decree in 1997, the CC-EPA covers the coast between the southern end of Pernambuco State and the northern part of Alagoas State, from the beach to the outer edge of the continental slope (Figure 1). Covering about 413,563 hectares, it is Brazil's largest federal MPA (One recently formed state EPA, the Sao Paulo State Government is larger) and the first federal Environmental Protection Area in Brazil to include coastal reefs [36]. Its major aims are the conservation of coral reefs, beaches, mangroves, and the manatee population, and to maintain the culture of coastal communities by regulating tourism and other economic activities [36]. The CC-EPA is under federal responsibility. A consultative council (CONAPACC) including government and non-government actors from the various levels supports the management of the MPA [37].

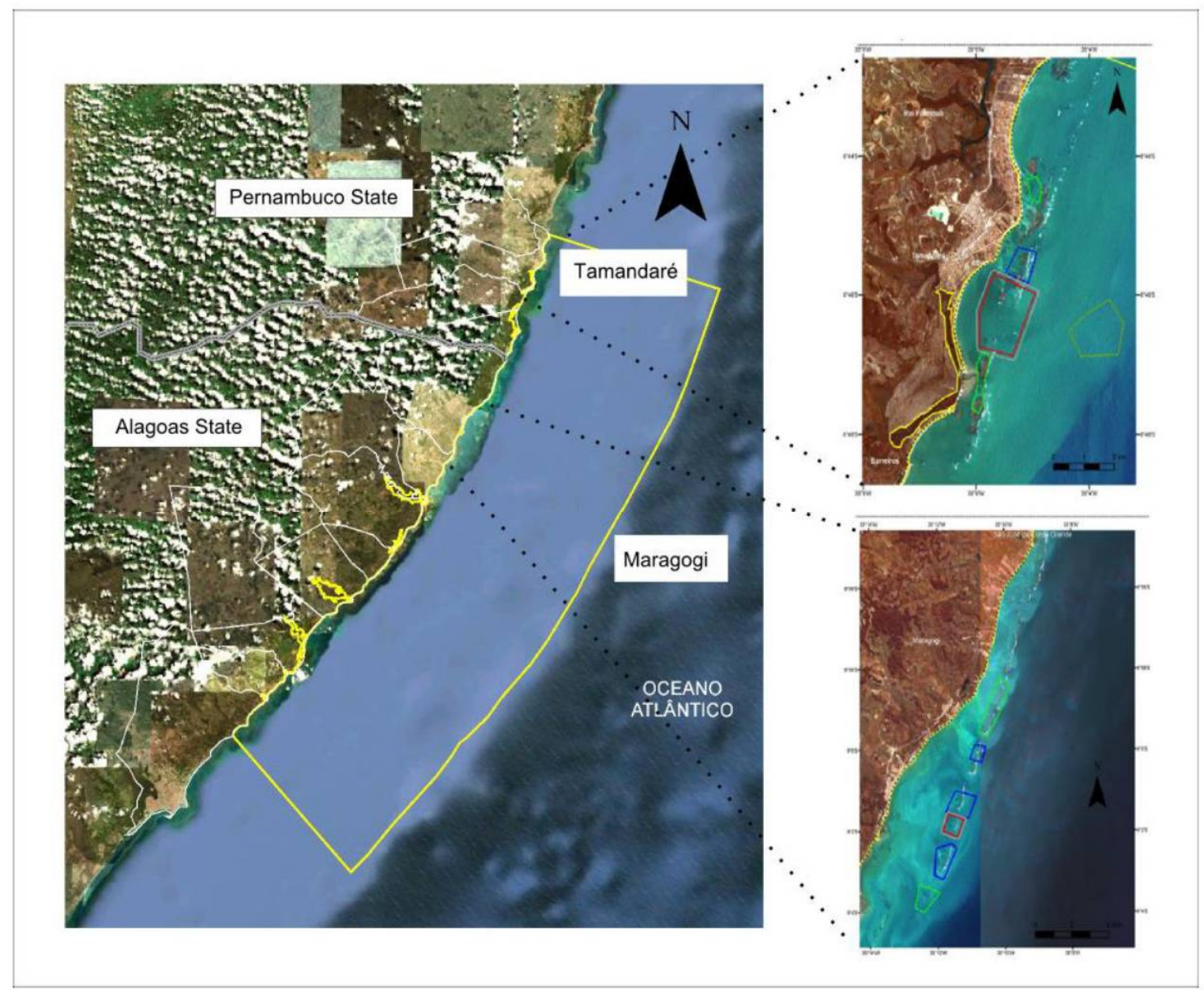

Figure 1. The Coral Coast Environmental Protection Area (CC-EPA) (adapted from [36]).

\subsection{The Local Study Sites}

Zoning is a central instrument for sustainable resource use in MPAs [15,17] and part of the CC-EPA Management Plan. Multiple small zones are implemented, and further ones are planned, to spatially organize the conservation area. These prescribe specific rules for the sea territories in the municipalities 
that are part of the MPA [36]. The two neighboring municipalities, Tamandaré and Maragogi, were selected as local study sites for the purpose of this research. Fishing and tourism are important sources of income in both areas, but the two study municipalities represent cases with varying success in implementing the CC-EPA's zoning rules. Whereas in Tamandare the regulations are effectively implemented, cheating on the rules in Maragogi was very common at the time of the research.

Tamandaré municipality in Pernambuco State, about $110 \mathrm{~km}$ south of the city Recife, has about 17,000 inhabitants and a population density of 173 inhabitants per $\mathrm{km}^{2}$, as well as about $14 \mathrm{~km}$ of coastline and $98.9 \mathrm{~km}^{2}$ of terrestrial territory [38]. A near shore coral reef area was closed in 1999 for all activities except research with the objectives to recover fish stocks; conserve/develop the natural environment; protect biodiversity; facilitate scientific research and environmental monitoring; and ensure exchange of organisms between marine areas [36]. Part of this closed area had formerly been intensively used by 'veranistas' (seasonal second home owners) with chairs, umbrellas, and 'churrasqueiras' (small barbecues) at low tide (This is documented in the video "Recifes Brasileiros" https: / / www.youtube.com/watch?v=rtvsEfOYzGE), and also frequented by artisanal fishers. 'Veranistas' and fishers were in the short term negatively affected by its closure. Nevertheless, the closed area is respected and can be considered effectively implemented until today [37].

Maragogi municipality in Alagoas State borders Pernambuco State and has 28,749 inhabitants and a population density of 86.6 per $\mathrm{km}^{2}$ [36]. Maragogi's coral reefs are about $5 \mathrm{~km}$ off the coast and form natural pools ('piscinas naturais'), which are a popular tourist destination in the state. Boats carry tourists to the natural pools in the reefs during low tide. According to a 2002 survey by the Coastal Coral Reefs Project, about 60,000 tourists per year and up to 729 visitors per day visited the Maragogi natural pools in the reef Galés at that time [36]. Today, the number of tourist is likely to be much higher with increasing tourism development in the municipality and after the opening of two more reefs for tourism (Taoca and Barra Grande since 2002) in response to increased demand. A number of regulations were introduced for all three reef areas thus designated for tourism to ensure the sustainable use of their coral reef ecosystems [36]. These rules include, among others, daily quotas for the number of boats and tourists per reef and day, and various rules on how to behave in the reefs etc. [36]. These rules were frequently cheated on, by, for instance, inadequate anchorage, disposal of garbage, stepping on the coral reefs, breaking off of corals by tourist to bring as 'souvenirs' and, fish feedings by the tourism operators to provide photo opportunities, etc. These unsustainable forms of behavior continue [10,39].

\section{Methods}

A multi-method approach was applied to collect the empirical data for this study. We integrated an adapted version of the net-mapping methodology with other qualitative methods including a policy review, key informant interviews, and participant observation. A summary of the methods is provided in Table 1.

The net-mapping approach was pioneered by Schiffer \& Hauck [31]. Our adaptation of the net-map methodology aims to elicit and visualize the knowledge and perceptions of ecosystem users of the formal and informal relations among actors, and their power in coral reef governance. The four-step procedure of our net-map interviews is summarized below (details are described in Appendix A, Supplementary Electronic Materials).

In step 1, we built a shared understanding of central concepts including "local marine area governance" and "management" between facilitators and participants, and among participants in the net-mapping session.

In step 2, participants identified regional marine governance stakeholders using the question 'Who affects or is affected by what happens in the (local) reef territories?' by writing the respective names of organizations or individuals on actor cards and fixing these to a large sheet of paper.

In step 3, participants identified the types and directions of marine governance interactions by drawing arrows between actor cards. Based on Schiffer and Hauck [31], five governance interaction 
types were distinguished: (i) information flow and capacitation; (ii) force/control; (iii) support; (iv) money flow; and (v) obstruction (differentiated by arrow colours in Figure 2).

In step 4, group members physically allocated a level of influence (from 0 to 4 , expressed by a corresponding number of dry "power" beans) to each identified governance actor.

Discussions on the reasons for constructing the map accompanied all stages of the net-mapping process and two facilitators took notes. Four net-mapping sessions of $2-3 \mathrm{~h}$. each were carried out in the two coastal communities of Maragogi and Tamandaré, one session with a group of fishers, and one with a group of tourism operators in each community. Net-mapping groups had 2-6 participants. Fishers were contacted at their residences and at the fishing colony, and tourism operators at their business locations. Our net-mapping groups are unlikely to be representative for their respective entire stakeholder community. Fishers used a range of different fishing methods, which were not representatively covered. The tourism operator net-mapping group participants were small-scale entrepreneurs, rather than the more aloof larger-scale urban-based tourism entrepreneurs. In line with the purpose of our research to analyse (differences in) stakeholder-specific knowledge and perceptions of the regional marine governance network, and the implications for stakeholder behaviour, our participant selection process focused on openness to participate, long experience in the respective reef-related activity, and in-depth knowledge of the region. While, given the small number of interviews, our results are indicative rather than fully representative for the respective stakeholder group in each of the study areas, they suggest an innovative approach to the analysis of perceptions of potential importance for environmental governance.

Net-mapping meetings were held in offices, business premises of tourism operators, and backyards of fishers' houses. The net-maps were digitalized with Gephi software [40].

A review of recent policy and other grey literature on the marine governance and management of the study area complemented the net-map interviews. In addition, three periods of participant observation (see [41], p. 342ff for details on the method) of reef tourism activities were carried out. The first period involved an initial round of participation in the offered reef tourism activities in the two municipalities over two weeks in June 2012. Later, over the course of four weeks in August 2013, the full variety of reef-related tourism options was repeatedly participated in using different operators in the municipality Tamandaré (2nd period of participant observation), and for four weeks in September 2013 in the municipality Maragogi (3rd period of participant observation). This served to gain an in-depth understanding of the coral reef use for tourism in the two municipalities. We also attended two regular CONAPACC meetings and one special session to learn about coral reef management practice in the area. Following the procedure described by Bernard [41], in-depth key informant interviews using open-ended, semi-structured interviews were carried out to contextually ground the findings of the net-map interviews. Interviews were conducted with key personnel responsible for developing management plans for the CC-EPA $(n=3)$, tourism operators $(n=2)$, fishers $(n=3)$, and NGO personnel $(n=1)$ (all male). The interviewees were identified through purposive sampling based on who was likely to possess highly detailed knowledge about the use and governance of the coral reef areas in the study region, and to ensure equal representation of the different stakeholder groups. The interviews focused on the recent development of the use of the coral reef territories, on the currently implemented management measures to ensure their sustainable use, and on understanding of whether the rules and regulations pertaining to the zoning rules are complied with in the study areas. The information gathered with these methods provided contextually grounded information to support the discussion of the findings of our net-map interviews. All empirical data for this article was collected in June 2012 and August/September 2013.

Prior informed consent was obtained from all informants who participated in this study. Moreover, the research was conducted in accordance with all ethical standards outlined in the Amended and Updated White Paper on Safeguarding Good Scientific Practice by the German Science Foundation [42]. 
Table 1. Summary of methods.

\begin{tabular}{|c|c|c|}
\hline Data Collection Method & Main Objectives & Participants \\
\hline Local policy review & $\begin{array}{l}\text { understand the currently implemented } \\
\text { management measures to ensure sustainable } \\
\text { use of the coral reefs }\end{array}$ & - \\
\hline Key informant interviews & $\begin{array}{l}\text { examine recent development in the region's } \\
\text { coral reef use } \\
\text { understand whether the CC-EPA's rules and } \\
\text { regulations implemented in the study areas } \\
\text { are complied with }\end{array}$ & $\begin{array}{l}\text { Interviews were conducted with key } \\
\text { persons involved in developing the } \\
\text { CC-EPA management plan }(n=3) \text {, } \\
\text { tourism operators }(n=2) \text {, fishers } \\
(n=3) \text { and NGO personnel }(n=1)\end{array}$ \\
\hline Participant observation & $\begin{array}{l}\text { learn about coral reef use and management } \\
\text { in practice }\end{array}$ & - \\
\hline Net-map sessions & $\begin{array}{l}\text { elicit the perceptions of ecosystem users of } \\
\text { the formal and informal relations between } \\
\text { actors in coral reef governance }\end{array}$ & $\begin{array}{l}\text { A group interview was conducted } \\
\text { with fishers }(n=6) \text { and tourism } \\
\text { operators }(n=2) \text { in Tamandaré, and } \\
\text { with fishers }(n=5) \text { and tourism } \\
\text { operators }(n=3) \text { in Maragogi }\end{array}$ \\
\hline
\end{tabular}

\section{Results}

\subsection{Shared Ecosystem User Perceptions of the Governance Realm}

The four-ecosystem user net-maps are visualized in Figure 2a-d. A total of 39 collective and individual actors from the academic, government, and ecosystem user realms were identified in all net-maps taken together. More details on the actors and their relations are provided in Appendix B supplementary electronic materials. The identified number of actors per net-map ranged between 13 and 24 actors (see Table 2 below).

With only two exceptions, the perceptions of the different net-mapping groups differed substantially. All four net-mapping groups perceived the government conservation institute ICMBio (Instituto Chico Mendes de Conservação da Biodiversidade) and the port authority of the Brazilian navy (Captitanía dos Portos) were regarded as highly central actors for setting rules and controlling reef area use (Figure $2 \mathrm{a}-\mathrm{d}$, red arrows).

Table 2. Numbers and sectors of reef governance actors perceived by fishers' and tourism operators' netmap groups.

\begin{tabular}{lccc}
\hline & Fishers & Tourism Operators & Totals \\
\hline Tamandaré & & & \\
Government & 5 & 8 & $10(36 \%)$ \\
Private sector & 7 & 7 & $8(29 \%)$ \\
Civil Society & 1 & 8 & $10(36 \%)$ \\
Total & 13 & 24 & 28 \\
Maragogi & & & $5(21 \%)$ \\
Government & 4 & 4 & $12(50 \%)$ \\
Private sector & 8 & 9 & $7(29 \%)$ \\
Civil Society & 4 & 5 & 24 \\
Total & 16 & 18 & \\
\hline
\end{tabular}

Totals take into account actors identified by both fishers' and tourism operators' groups (see also Table A1 in Appendix B, electronic supplementary materials).

\subsubsection{Location Specific Perceptions}

The Tamandaré closed area was seen as effectively closed for all activities except research by key informants and both net-mapping groups. Both Tamandaré net-mapping groups perceived ICMBio as directly implementing the rules of the local closed area (indicated by the red arrows in Figure 2a,b) and described management rules for the closed reef area ('area fechada') as well implemented. 
The Tamandaré tourism net-mapping group was concerned about uncontrolled high-speed jet-skis and speed boats endangering bathers, fishers, and others (black arrows, Figure 2a). Both Tamandaré net-mapping groups saw a similarly diverse realm of private sector and marine government actors (Table 2). Marine area zoning in Tamandaré was, according to the fisher and the tourism operator group (Figure 2a,b), accompanied by capacity-building and mutual information exchange between fishers and university and NGO lecturers (green arrows, Figure 2a,b). Both net-maps from Tamandaré (Figure 2a,b) show the universities and environmental NGOs with their capacity-building activities as medium to very powerful in their pursuit of sustainable reef area use and conservation.

Both Maragogi net-mapping groups regarded ICMBio as directly and effectively enforcing the exclusion of fishers from reef tourism zones (red arrows, Figure $2 c, d$ ), but as very ineffective in controlling the diverse and powerful tourism operators (also marked by red arrows in Figure 2c,d, yet the difference explained in the net-mapping sessions). Both Maragogi net-mapping groups reported rule enforcement on tourism enterprises as delegated to town government ('municipio') and state police with serious implementation problems vis-à-vis the numerous and diverse tourism-driven private sector actors, and with fewer governance and government actors (Table 2). Neither fishers nor tourism operators saw the universities as playing any role in Maragogi reef governance.

While both local net-mapping groups saw the fishing colony as influential in Maragogi reef governance as the political representative of fishers, both regarded other civil society organizations, such as the associations of smaller tourism operators and NGOs, as much weaker (Figure 2c,d).

Fisher and tourism operator groups differed in the number and types of reef stakeholders and reef stakeholder interactions they identified (Table 2).

\subsubsection{Fishers' Perceptions}

Fishers identified fewer governance actors and a less dense reef governance network than the tourism operator groups (Table 2 and Figure $2 b, \mathrm{~d}$ ). Tamandaré fishers named only just over half the marine governance actors that local tourism operators considered important (Table 2). Tamandaré fishers also reported much fewer connections to the civil society realm than the Tamandare tourism operator net-mapping group, and saw their fishing colony as not exerting any influence on reef governance. The Tamandaré fisher net-mappers also felt themselves as mainly being subject to a high "force and control" influence from the CC-EPA management authorities ICMBio and the Brazilian Institute for the Environment and Renewable Resources (Instituto Brasileiro do Meio Ambiente e dos Recursos Naturais Renováveis, IBAMA) that was supported by town government (red arrows, Figure 1b). Fishers in Maragogi also felt similarly firmly controlled by the diverse public authorities in the marine realm (red arrows, Figure 2d). They self-reported as feeling only supported by the fishing colony (yellow arrow, Figure 2d). The Maragogi fisher net-mapping group (Figure 2d and Table 2) saw very few organized civil society actors in local reef governance, regarded zoning as particularly strictly implemented where fishing was concerned (red arrows, Figure $2 c, d$ ), and emphasized a lack of capacity-building for fishers to engage in small-scale reef tourism (i.e., tourism speedboat operators). Maragogi fishers reported information flows (green arrow, Figure 2d) only to the tourism sector, and identified their fishing colony as the only support (yellow arrow, Figure 2d) for fishers. Nonetheless, some former Maragogi fishers who had converted their boats for tourism were assuming some new roles. This is reflected in their more diverse links to other actors (Figure 2b). However, as the group of small boat owners, they also felt disadvantaged by the quota system for reef tourism, which allows far higher tourist numbers for larger boat operators.

\subsubsection{Tourism Operators' Perceptions}

Tourism operators in both sites reported a more diverse marine governance network than fishers, and were linked more diversely and strongly than fishers (Details on the individual actors mentioned in the net-map interviews are found in Appendix B, electronic supplementary materials). 
Tamandaré tourism operators reported a diverse governance realm with government, civil society, and the private sector fairly equally represented and with more information flows (green arrows, Figure 2a) from and to them, as well as more supportive relations (yellow arrows, Figure 2a) than in any of the other net-maps. Moreover, Tamandaré tourism operators presented the most balanced distribution between different actors and link types.

In Maragogi, tourism was developing dynamically. Zoning for the reef areas had become national law with the CC-EPA Management Plan in 2013, and fishing was prohibited in the tourism zone. Tours to the reefs were only allowed during low tide so that visitors could securely stand in the water. Three boat types took tourists to the reefs. The smallest, speed boats ('lanchas'), take about six persons. The largest, catamarans, take about 54 persons. The third type of tourist boat, the converted former fishing boat ('escuna/barco adaptado'), took about 12 persons per vessel. Tourism boats required a license, and for each local reef area, the same fixed number of boats per boat type was allowed per day. This limited access to reef-based tourism incomes for the many less well-off owners of small boats. The few wealthier tourism entrepreneurs with large 'catamarans', who mostly came from the state capital and beyond, were thus able to carry a much greater number of tourists. The tourism catamaran owner association, and the often personally linked owners of the tourist "receptions", had successfully lobbied for opening additional reef areas for tourism and for tourist quotas that favor the large boats of wealthier entrepreneurs. One civil society actor that might counterbalance the "big business bias" in Maragogi reef governance was seen to be the fishing colony. This represents fishers, but not the growing number of fishermen that had recently become small tourism entrepreneurs and formed their own association (Operators of converted fishing boats for tourism in Figure 2c).

The Maragogi tourism operator net-mapping group, which did not include any of the powerful catamaran owners, reported that the local quota system for transporting tourists to the reefs was not respected, illegal fish feeding was encouraged by photographers, and the collection of corals as souvenirs by tourists tolerated. Maragogi tourism operators saw mainly money flows (blue arrows, Figure 2c) and force-and-control relationships (red arrows, Figure 2c) with supportive relationships (yellow arrows, Figure 2c) only between sector representatives and their associations. They deplored inequitable access to reef areas between owners of small and large tourist boats, between small and large entrepreneurs, and between fishers and tourism entrepreneurs, as well as the missing transparency about the use of the monies raised through the per head reef tourism levy. They regarded these shortcomings as causing wide-spread infringements of local reef management rules. Maragogi's tourism operator net-mapping group saw reef governance as driven by private and government sector actors, and revolving around tourism income without any important civil society actors or effective capacity-building beyond the activities of the fishing colony, whose remit excludes tourism (Figure 2c yellow nodes and arrows). 


\section{a) Tamandaré tourism operators}

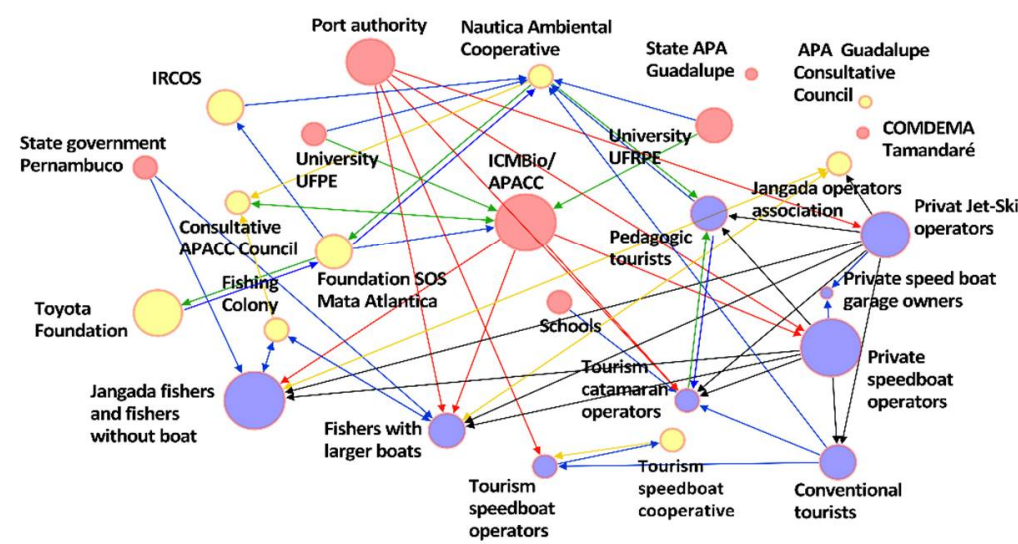

c) Maragogi tourism operators

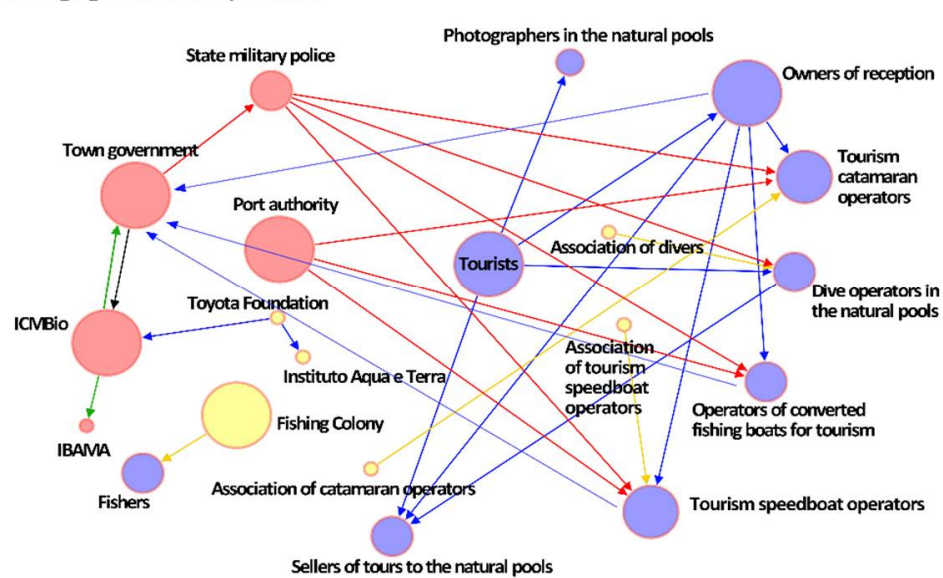

\section{b) Tamandaré fishers}

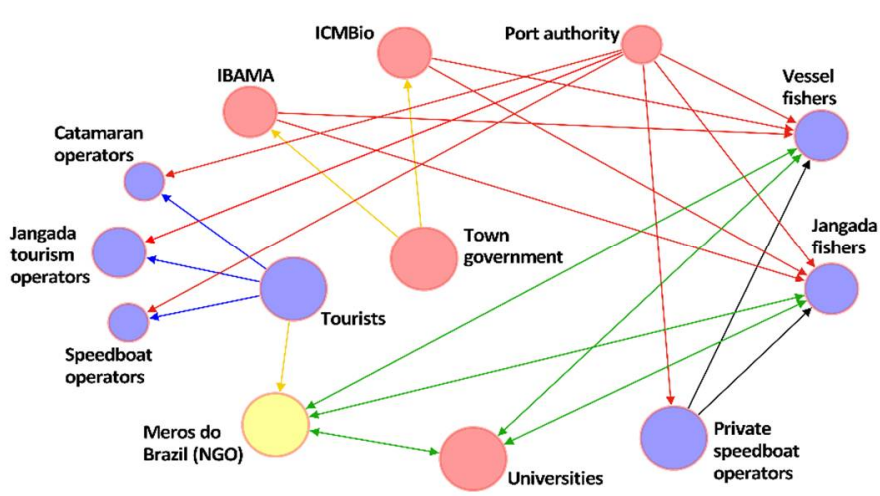

d) Maragogi fishers

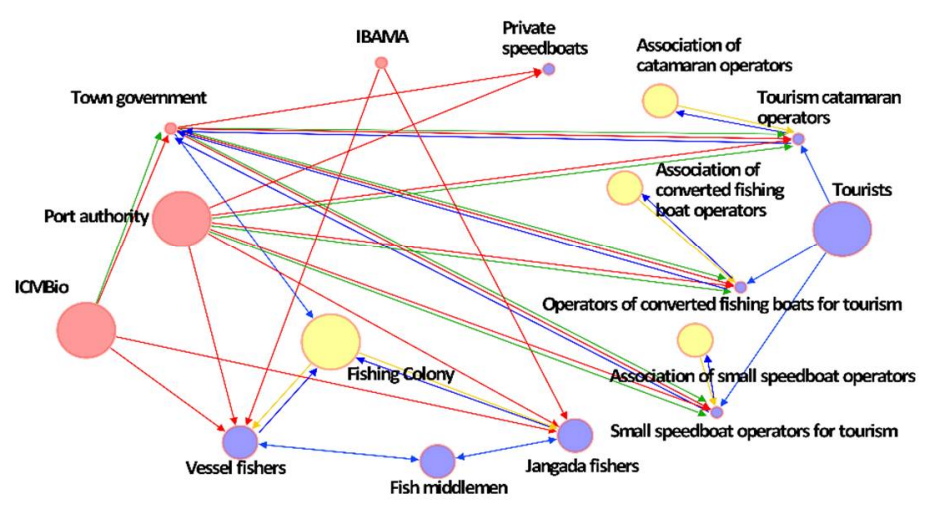

Figure 2. Governance actors, their interaction and influence as perceived by ecosystem users in Maragogi and Tamandaré. Coloured nodes represent actor types: red nodes—-government actors, blue nodes—private sector actors, yellow nodes—civil society actors. Node size shows an actor's influence and power on coral reef management (with bigger nodes indicating more). Coloured arrows represent types of flows/social relations between actors: green arrow-information flow/capacitation, red arrow—force/control, yellow arrow—support, blue arrow—money flow, black arrow - obstruction. For details about the acronyms and actors see Appendix B, electronic supplemental material. 


\section{Discussion}

\subsection{Towards Sustainability-Enhancing Regulations for the Use of Coral Reef Territories}

Perceptions are socially constructed, informed by personal experience, and under the influence of a range of different forms of knowledge and understanding [23,29,43-46]. The field of environmental psychology is of ultimate relevance for studies on environmental perceptions and governance, and has been recognized and moved closer to the field of natural resource use and management over the past decade. Individual perceptions can influence (individual and group) behaviour in a diversity of processes. The analysis of perceptions is therefore central for understanding natural resource use and management (including strategies to cope with environmental change), and needs to inform decision-making in environmental governance [24,28,47-49].

All ecosystem users in our net-mapping groups perceived a government-led, centralized structure of local marine area management. Beyond this, perceptual differences relating to marine governance actors and their interactions exist for the CC-EPA as a whole, and between locations and ecosystem user types. Our net-maps show how fishers, tourism operators, and other ecosystem users see themselves as part of specific webs of social relations each with an associated set of power asymmetries. Fishers and tourism operators relate to these social networks as they perceive them from their own particular social and spatial/institutional positions, and in relation to their own interests and vulnerabilities [29]. Thus, the different de facto marine governance experiences of our net-map participants set the scene for their actions.

\subsubsection{Influence and Legitimacy}

All net-mapping groups considered federal government institutions as the most influential actors in planning and enforcing marine regulations. The integration of local, traditional, and scientific knowledge is today widely seen as enhancing the quality of management outcomes [50] via the involvement of stakeholders in deliberation and planning so as to increase the equity and legitimacy of management measures [51,52]. In Brazil, the Environmental Protection Areas (EPAs) generally employ a mixed approach towards marine governance [53] to legitimize interventions and integrate local knowledge. The CC-EPA in our study area operates with a consultative council (CONAPACC) of representatives from organized civil society who are consulted on management structures, processes, and rules. The formulation of marine regulations is meant to be subject to this consultation before decisions are taken by ICMBio- the official managers of CC-EPA. Ecosystem users in both study areas, however, perceived ICMBio and IBAMA as applying a "command-and-control" approach with at best a marginal influence of the consultative council on local marine governance. Both agencies were not seen as providing information and training, an important tool for legitimacy building and implementation where government personnel is scarce and/or physically distant. In Tamandaré, where ecosystem users regarded environmental education and capacity-building as successfully carried out by university and NGO personnel, a somewhat greater consensus was apparent. In Maragogi, knowledge deficits, in particular on the implications of fish feeding and coral breaking, apparent among photographers, divers, and other tourism operators (see electronic Appendix B), was one of the reasons for continuing destructive behavior towards the reef.

Communication and capacity building by universities, NGOs, and foundations in Tamandaré thus stand in contrast to the perceived lack of capacity-building in Maragogi. Building an informed consensus among ecosystem users and other relevant reef stakeholders through information exchange and capacity-building appears to have supported effective implementation of coral reef related regulations in Tamandaré. That knowledge sharing increases legitimacy and facilitates implementation of reef use restrictions is an important lesson for local marine governance. 


\subsubsection{Equity}

Maragogi net-mapping groups' concern about the whereabouts of reef tourism fee monies, and the various pro-wealthy biases reported by Maragogi net-mappers, confirm not only that local authorities are not necessarily equipped for or oriented towards sustainable coastal management [18], but also that ineffectiveness, corruption, elite appropriation of benefits, nepotism or the unsuitable "delegations of duties" result in general rule breaking.

The heavily used reef tourism zones in Maragogi bias access in favor of wealthy outsiders and deepen economic inequalities between ecosystem users. The licensing rules of the Maragogi zoning scheme, for instance, puts the emerging group of local small-scale tourism entrepreneurs and the fishers at a clear disadvantage vis-à-vis larger urban-based entrepreneurs. Discussions with both local net-mapping groups showed that the perceived inequities in access to reef-related incomes are a strong driver of unsustainable reef use in Maragogi. A municipal law under discussion at the time was to ban licenses for new tourism boats. This would close the tourism livelihood options to local fishers with potential rebound effects for conservation, and cement the bias of Maragogi reef governance in favour of larger and wealthier tourism enterprises. Biases in rule-making, implementation, and enforcement relating to the use of the coral reef territories are thus undermining the social and ecological sustainability of reef use. As a wider lesson for reef governance, we suggest that without the perception of an equitable rule system, its implementation will be fraught with failure.

An important step towards more equitable coral reef access rights in Maragogi, although in the current socio-economic structure perhaps not necessarily towards sustainable reef management, was the inclusion of adapted fishing boats in the reef tourism quota system. The Fishing Colony was reported to have successfully lobbied for this, and in return to be assisting ICMBio with preventing fishing in reef tourism zones. Confirming our conclusion about the criticality of perceived equity for effective conservation, this example shows how a more equitable distribution of reef-related income was followed by better collaboration in implementing conservation rules.

In contrast, the treatment of all potential users of the Tamandaré closed area was perceived as generally equitable. This reduced the likelihood of conflicts and of rule breaking in this study location. Capacity-building activities that increased fishers' awareness of potential fishery gains from spill-overs from the closed marine areas, and that also provided fishers with income in the lean seasons, also reduced the perceived clash of interests between conservation and fisheries in Tamandaré.

\subsubsection{On the Net-Mapping Method}

Net-mapping can uncover sources of conflict and potentials for cooperation, and it can facilitate knowledge exchange and learning processes among actors in coral reef governance $[54,55]$.

Although in both study locations tourism operators generate income from ecosystem services and fishers extract marine resources and rely on the social security system in both areas, Tamandare and Maragogi reef use and institutional contexts differ greatly. Each of our ecosystem user net-mapping groups perceived a part of the reef governance system which is most important for their livelihoods from their particular vantage points. What was reported and what was omitted emerged from the respective stakeholder realities. Differences in perception emerged from social relations and power structures, and from the unequal access to information and resources these generate. Different levels of reasoning capacity and of institutional expertise may have also generated divergent perceptions even where the same information was available.

The net-mapping approach can provide information about how a governance system is seen by different stakeholder groups. Good knowledge of such perceptions allows us to better trace the drivers of ecosystem-relevant stakeholder behaviour, and identify possible related shortcomings in the governance system [56]. An integrated approach to identifying perceptions and analysing them as behavioural drivers will strengthen future sustainability research. Our net-maps, and the discussions that accompanied their construction, reveal social divisions, conflicts, and stakeholder-specific misinformation and information gaps. These help us to better explain human behaviour towards 
the marine environment. Perceptions arise structurally, but also from the personal social networks and histories of individuals. Representativeness is an issue: even within a specific ecosystem user group, the perceptions a net-map reflects depends on who is in the respective net-mapping group. For instance, Maragogi tourism operators were diverse and divided. It is thus important to document the background of net-mapping group members, and to conduct additional net-mapping sessions with initially omitted stakeholders. To gain a more comprehensive understanding, such studies can be complemented with a larger set of ecosystem stakeholders, including other direct ecosystem users and other governance actors to generate a fuller picture of the conceptual frameworks, perceptions, and incentive systems which underlie the current behaviours of a greater number of important marine governance actors. Timing is also important: short meetings are often insufficient for comprehensive discussions, and net-mapping meetings which last more than $90 \mathrm{~min}$ become ineffective as people's attentions wane.

Net-mapping needs to be complemented with grounded contextual knowledge. An important rule for the "net-map-fieldworker" is, however, not to prompt while the net-mapping group is at work. Thus, while a discussion initiated with information gained elsewhere is important to better understand local complexities, net-mapping the perceptions of a stakeholder group needs to be conducted without the facilitator attempting to alter stakeholder perceptions in the net-mapping process itself.

As used in this study, the net-mapping method highlights perceptions, and perceptual differences on reef governance. Ecosystem user perceptions may appear biased or under-informed to those with differently rooted knowledge, who often have greater power to claim legitimacy and truth for their own perceptions. We assert that a better knowledge on such diversity and differences in ecosystem user perceptions is actually an underexplored approach for informing policy and rule-making.

\subsubsection{Net-Mapping as a Catalyst of Action}

Net-mapping links knowledge, and thus, can catalyse social organization and action $[31,54,55]$. Problems with careless private speedboat drivers impeding fishery and tourism were discussed in Tamandaré's COMDEMA (a municipal council with deliberative rights, see Reference [57] for details) shortly after our Tamandaré net-mapping sessions. A technical working group was created to extend marine zoning, regulate marine traffic, and create a sustainable tourism zone.

A COMDEMA was re-activated in Maragogi before our net-mapping session wherein a participatory environmental micro-zonation for the tourism zone was conducted, and a capacitation event on good conduct for marine tourism facilitators was planned shortly after our net-mapping session. These activities were initiated in the Maragogi COMDEMA to address equity concerns and conflicts among user groups, and they increased the legitimacy of tourism zone regulations. Participants discussed an intended closed reef area in Maragogi, modelled on that in Tamandaré. During our fieldwork period, however, neither net-mapping group as yet saw the Maragogi COMDEMA as influential in reef governance. This illustrates that stakeholder perceptions need to be monitored over time to gain an effective handle on perception-guided human behaviour towards ecosystems. Different points of leverage for adaptive governance may be identified as stakeholder perceptions of ecosystem governance change. To best inform environmental governance and management, perception studies thus need to identify differences between governance stakeholders, and pinpoint changes over time.

Since 2017 and during all of 2018 (five years after our interviews), the CC-EPA Management Plan is under revision, and the zoning plan that now includes zones for fishing, tourism, and conservation, is also under discussion. This is being conducted through local consultations, and thus, may represent an opportunity to consider and include on-the-ground ecosystem user perceptions more deeply. Net-mapping could be a good tool to both guide and evaluate the evolving balance of forces and distribution of benefits in this process. 


\section{Conclusions}

This study adopted a participatory, mixed method research approach to explore ecosystem user perspectives on environmental governance. It showed that perceptions of reef governance networks and interactions, and of the associated power and influence complexes, differ between different ecosystem user types, as well as between places. We argue, and show, that the analysis of such perceptions can contribute to policy decision-making. Thus, this study contributes to the growing body of literature and evidence showing that research on environmental perceptions needs to move out of an under-represented, hard to tackle shadow into the academic and cross-faculty discourse on environmental governance and wider sustainability studies. Our approach and findings serve to disentangle complex settings and conflicts over resource usage, and pave the road for more equity-oriented policy-making. In future studies, perceptions will need to be investigated, recorded, and analysed over time in a more standardized manner. Research on stakeholder perceptions to date has been done mostly on a case-to-case basis [58]. The potential now exists for the wider research community to use this field to work across the natural and social sciences, as well as humanities' disciplines. The important policy leverage arenas to render marine governance more effective are inclusiveness, knowledge building, legitimacy, and equity, and if done with methodical care, net-mapping can explore these in inclusive and empowering ways.

In our particular study area, this means that more effective territorial regulations may be generated by improving the equity of current local rules on reef use, by building capacity for direct ecosystem users, and by better integrating currently marginalized stakeholder interests within, and between ecosystem user groups. Municipal- and town-level institutions in both study areas need capacitation to better fulfil their roles in the multi-level governance system which is emerging with political decentralization [15]. For instance, municipal councils (COMDEMAs) are legally entitled to assume a strong environmental governance role, as had formerly been achieved in Tamandaré [57]. The consultative council of the CC-EPA is another important regional tool with wide responsibilities [59]. These options for ecosystem user participation on regional and local levels need to be better communicated, re-assessed, and adapted on a regular basis to capture change in perceptions, and decisions need to be followed by publicly visible actions. The consultative status, to which all MPA categories except the Extractivist Reserves are confined in Brazil (SNUC 1980, [18]), gives the final decision-making rights over protected areas to the public-sector management body (ICMBio). Where use rights to natural resources on which local livelihoods depend are decided, a more influential (i.e., deliberative) position for local ecosystem users is desirable. This supported by the type of research on perceptions of the environment, and of its governance along the lines indicated in this study, is likely to enhance the sustainability of human-nature relations. The organizational strengthening of civil society organizations, especially the small tourism operator associations and fishing colonies, will also need to be addressed to reduce equity concerns.

While we have not started this work within the confines of any particular theoretical school, a political economy framework that focuses on the (perceived) exercise of relative power and influence between stakeholders, and on resultant distribution of costs and benefits between stakeholders (i.e., on how important actors perceive the "winners and losers"), suggests itself (e.g., [60]). Adger and colleagues [60] suggest that action between directly interested parties in any decision, given the power relations between them, does not come about without perceived gain through the bargain is of continuing pertinence. Confirming this, the differences in conservation compliance between Tamandare and Maragogi was related to the distribution of its costs and benefits.

Moreover, recent research emphasizes that the analysis of structure and dynamics of social networks generates helpful insights for conservation efforts (see e.g., [61-63]). Our findings are in line with these studies showing that methodologically solid investigations of usually complex and varying perceptions, in our case of the divergent stakeholder-specific perceptions of reef governance networks, and of who is seen to be able or unable to leverage power relations hold important messages for environmental governance. 
Author Contributions: M.G. and P.G. conceived the study, and collected and analysed the data; B.F. contributed her long-standing expertise of working in the area; M.G. led the writing of the paper with substantial contributions by P.G., B.F., and A.B.

Acknowledgments: We thank Mauro Maida for insightful comments on an early version of this article from his extensive knowledge of the study region, and Eike Holzkämper. We are also grateful to the fishermen and tourism operators of Tamandaré and Maragogi who with their time, knowledge, and openness made this study possible, and last but not least, to three anonymous reviewers for their comments and suggestions. A much earlier version of this article was included in the PhD-Thesis of P.G. [37]. We acknowledge funding provided by the Center for Tropical Marine Research (ZMT) Bremen. P.G. acknowledges financial support from the Alexander-von-Humboldt $(\mathrm{AvH})$ professorship for Environmental Economics of the University of Osnabrück (UOS), and from the Deutsche Forschungsgemeinschaft (DFG) and Open Access Publishing Fund of Osnabrück University.

Conflicts of Interest: The authors declare no conflict of interest. The sponsors had no role in the design of the study; in the collection, analyses, or interpretation of data; in the writing of the manuscript, and in the decision to publish the results.

\section{Appendix A Description of Net-Map Method as Used in this Study}

Net-mapping, as adapted in this research, aims to elucidate and visualize implicit knowledge and stakeholder perceptions of the complex interplay of formal and informal relations and power in coral reef governance. Moreover, it serves to uncover sources of conflicts and potentials for cooperation, and aims to facilitate knowledge exchange and learning processes. While the tool can produce both qualitative and quantitative data, it was used for qualitative data collection in this research.

Preparation of net-map sessions: A net-map group with a minimum of 2, but ideally 6-8 participants, and one or two facilitators were present. A large sheet of paper, Post-its, coloured pens and coins or influence grains were available.

Step 1: To build a joint understanding of the concepts of "marine area" and of "marine governance" within the net-map group, we explained marine area as follows: "An area of sea which people know. Ideally, it has some sort of boundary (i.e., the waters around an island (island exclusion zone), an MPA with marker buoys or the 200 miles Economic Exclusion Zone that maritime countries have a right to). Sometimes marine areas have few boundaries (e.g., fishing grounds)". For governance, the following working definition was used in the groups: "All rules, including laws but also customs and local habits relating to the marine space make the "governance" framework. What people do to a marine area is "management" or management-related actions. These affect the state of the fish, corals, and other ecosystem components. Marine area related actions are thus what people and organizations do to a marine area (e.g., fish, make rules, protect a species obey—or not the rules (e.g., discard garbage, feed fish)".

Step 2: The net-map group identified those who affect or are affected by the marine area in question, (i.e., the stakeholders). We placed a large sheet of paper in front of the net-map group and asked them to think of all individuals, groups, or organizations that affect the governance of "their" coral reef region. The mentioned stakeholders were noted on coloured "stakeholder cards" (red for government stakeholders, yellow for non-government organizations and civil-society associations, blue for private sector stakeholder groups) and glued on the paper.

Step 3: The net-map group described the different types of links between identified stakeholders. Using coloured markers, different types of links were depicted as differently coloured arrows between the stakeholder cards. Based on the suggestion by Schiffer \& Hauck [31], we adapted the link types according to the circumstances of the study areas and the objectives of the study. Green arrows were used for information flux, red for exercise of force/control, yellow for provision of support, and black where an action of one stakeholder was seen to obstruct the objectives of another.

Step 4: Net-map group participants were asked to judge how much influence they considered the different stakeholder types to have on the use of the reef-based marine area in question. For this, participants built so-called "influence-piles" by using our "power beans" (local dry beans/'fejão'). To represent the degree of influence of the respective stakeholder (group), between 0-4 power beans were placed by group participants next to each of the stakeholder cards. The more influence an actor 
was perceived to have on the use of the marine area in question, the higher the number of beans assigned with zero representing no influence at all. Discussions of the reasons for the thus constructed map of relative power and influence followed.

\section{Appendix B Supplementary Electronic Material}

This appendix illuminates actor-specific information relating to ecosystem user perceptions of social interaction patterns, and of power and influence in the governance of coral reef territories in two sites in a larger Marine Protected Area, in the Tamandaré and Maragogi municipalities in the CC-APA. While the main paper presented results on perceptions according to locality and ecosystem user group type, this appendix provides additional actor-specific information for each site.

Table A1 lists all actors named in any of the four net-maps constructed in this study. Subsequently, we explain (most of) the individual actors in Figure 2 of the main article text and provide some additional information.

Table A1. CC-EPA Reef Governance Actors for Tamandaré and Maragogi marine areas as perceived by fisher and tourism operator net-map groups.

\begin{tabular}{|c|c|c|c|c|}
\hline \multirow{2}{*}{ Actors } & \multicolumn{2}{|c|}{$\begin{array}{c}\text { Tamandaré, } \\
\text { Mentioned by }\end{array}$} & \multicolumn{2}{|c|}{$\begin{array}{c}\text { Maragogi, } \\
\text { Mentioned by }\end{array}$} \\
\hline & Tourism & Fishers & Tourism & Fishers \\
\hline Town government & & $x$ & $x$ & $x$ \\
\hline Port authority & $x$ & $\mathrm{x}$ & $\mathrm{x}$ & $\mathrm{x}$ \\
\hline IBAMA & & $x$ & $x$ & $x$ \\
\hline ICMBio & $\mathrm{x}$ & $x$ & $\mathrm{x}$ & $\mathrm{x}$ \\
\hline State military police & & & $\mathrm{x}$ & \\
\hline University UFRPE & $x$ & $x$ & & \\
\hline University UFPE & $x$ & $x$ & & \\
\hline Schools & $\mathrm{x}$ & & & \\
\hline State government Pernambuco/Chapeu de Palha & $x$ & & & \\
\hline COMDEMA & $\mathrm{x}$ & & & \\
\hline State APA Guadalupe & $\mathrm{x}$ & & & \\
\hline Consultative Council of CC-EPA & $x$ & & & \\
\hline Consultative Council Guadalupe EPA & $x$ & & & \\
\hline Conventional tourists & $\mathrm{x}$ & $x$ & $\mathrm{x}$ & $\mathrm{x}$ \\
\hline Pedagogic tourists & $\mathrm{x}$ & & & \\
\hline Tourism catamaran operators & $x$ & $x$ & $x$ & $x$ \\
\hline Tourism speedboat operators & $x$ & $x$ & $x$ & $x$ \\
\hline Operators of converted fishing boats for tourism & & & $\mathrm{x}$ & $\mathrm{x}$ \\
\hline Owners of reception & & & $\mathrm{x}$ & \\
\hline Dive operators in the natural pools & & & $x$ & \\
\hline Photographers in the natural pools & & & $x$ & \\
\hline Sellers of tours to the natural pools & & & $\mathrm{x}$ & \\
\hline Speed boat garage owners & $\mathrm{x}$ & & & \\
\hline Private speedboat and jet-ski operators & $x$ & $x$ & & $x$ \\
\hline Jangada fishers & $x$ & $x$ & $x$ & $x$ \\
\hline Vessel fishers & $x$ & $x$ & $x$ & $\mathrm{x}$ \\
\hline Fish middlemen & & & & $\mathrm{x}$ \\
\hline Fishing colony & $x$ & & $x$ & $x$ \\
\hline Association of divers & & & $x$ & \\
\hline Association of converted fishing boat op. & & & & $\mathrm{x}$ \\
\hline Association of tourism speedboat operators & $x$ & & $\mathrm{x}$ & $\mathrm{x}$ \\
\hline Association of catamaran operators & & & $\mathrm{x}$ & $\mathrm{x}$ \\
\hline
\end{tabular}


Table A1. Cont.

\begin{tabular}{|c|c|c|c|c|}
\hline \multirow{2}{*}{ Actors } & \multicolumn{2}{|c|}{$\begin{array}{c}\text { Tamandaré, } \\
\text { Mentioned by }\end{array}$} & \multicolumn{2}{|c|}{$\begin{array}{c}\text { Maragogi, } \\
\text { Mentioned by }\end{array}$} \\
\hline & Tourism & Fishers & Tourism & Fishers \\
\hline Jangada operators association & $\mathrm{x}$ & & & \\
\hline Instituto Aqua e Terra & & & $\mathrm{x}$ & \\
\hline Toyota Foundation & $x$ & & $\mathrm{x}$ & \\
\hline Meros do Brazil (NGO) & & $x$ & & \\
\hline Foundation SOS Mata Atlantica & $x$ & & & \\
\hline Nautica Ambiental Cooperative, Tamandaré & $x$ & & & \\
\hline IRCOS (Instituto Recifes Costeiros) & $x$ & & & \\
\hline
\end{tabular}

\section{Tamandaré Net-Maps (Figure 2a,b in Main Text)}

The two local net-map groups, one with six fishermen and the other with two reef tourism operators, identified a total of 28 local reef stakeholders from the private business sector, government, civil society organizations, and NGOs. The Tamandaré net-map groups' perceptions differed greatly, especially in relation to the role of civil society organizations in the governance of local reef areas. Tourism operators provided a much more detailed view of the governance system than fishermen. Four categories of direct reef area users from the private sector were identified for Tamandaré: (1) fishers using a variety of fishing gears in the near-shore coral reef area; (2) tourists who visit the coral reefs; (3) tourism operators; and 4 drivers of private speedboats and jet-skies.

The national government department ICMBio (Instituto Chico Mendes de Conservação da Biodiversidade) was identified by both net-map groups as the prime planner and enforcer of marine environmental regulations (ICMBio was created in the restructuring of the Brazilian Institute for the Environment [Instituto Brasileiro do Meio Ambiente e dos Recursos Naturais Renováveis, IBAMA]. Both IBAMA and ICIMBio are now departments are under the Ministry of the Environment (MMA). MMA and IBAMA are officially responsible for policy-making, implementation, and enforcement relating to the conservation and sustainable use of natural ecosystems [64]. ICMBio is officially in charge of establishing and managing federal conservation units including the CC-EPA [65]). The tourism operator net-map excluded IBAMA as an actor and represented ICMBio as the prime enforcer of marine environmental regulations in the marine conservation unit CC-EPA. In conjunction with its rule setting rights, the group perceived ICMBio's influence as very strong (4 grains in Figure 2). The fisher net-map group, on the other hand, identified both the federal IBAMA and ICMBio, but considered them as the same actor "that keeps changing names". Fishermen saw the federal IBAMA as enforcing marine zoning and fisheries laws and regulations and ICMBio as the managers of protected areas.

The Port Authority of the Brazilian Navy (Capitanía dos Portos/Marinha do Brasil) was seen by both Tamandare net-map groups as the responsible and effective institution for regulating maritime traffic and safety including vessel movements. The town government (prefeitura) was seen by both net-map groups as responsible for the regulation and organization of activities in local marine waters. The fisher net-map group saw the elected town government as supportive: to fishers with projects, and to ICMbio and IBAMA by attending and collaborating in meetings. The tourism operator net-map group, on the other hand, explicitly negated any influence by the town government on the local coral reef areas since they saw the latter as not assuming their responsibilities. Tourist operators also saw no regulatory or enforcement role of the town government in the local marine governance system.

Schools were an important stakeholder for Tamandaré tourist operators since environmental education was seen to be needed for improving marine governance. Tourist operators identified a money flow from schools to catamaran operators for conducting tours, but regarded schools as of limited overall influence (1 grain in Figure 2). 
Tourism operators emphasized the state government of Pernambuco's lean season training programs ('Chapeu de Palha'). For the attendance of the Pernambuco State environmental capacity-building and alphabetization programs, fishers are given money as compensation for the time spent in training. Tourism operators, however, claimed that such trainings of local fishers are not always implemented effectively and attributed low influence on the state government (1 grain in Figure 2). The state government program was not mentioned by the Tamandaré fisher net-map group, but the knowledge obtained in "lectures", and the monetary compensation for attending lectures was discussed.

Two federal universities, the Federal University of Pernambuco (UFPE) and Rural Federal University of Pernambuco (UFRPE), were identified as reef governance actors by tourism operators. Fishers mentioned "the university" without distinguishing between the two. The fisher net-map group acknowledged the ecosystem-relevant information they obtained from lectures by university biologists during the low (fishing) season as a source of income and of valuable information. The fishers did not mention the state government program. These lectures and capacitation activities are funded by the above described state government program. Emphasizing that their own knowledge contributes to academia, fishers described "the university" as of very high influence on what happens in the coral reef areas (4 grains in Figure 2). Tourism operators saw the two federal universities as providing information to ICMBio, and funds to support activities of the tourism operator Cooperativa Nauticá Ambiental, but saw only a minor influence of the universities on the reefs ( 2 grains to UFRPE; 1 grain to UFPE in Figure 2).

The Tamandaré tourism net-map group identified eleven NGOs and civil society entities as affecting Tamandaré coral reef governance. In contrast, Tamandaré fishers only perceived one civil society actor, the NGO Meros do Brazil, which was not mentioned at all by the tourism operator group. The fisher net-map group acknowledged this NGO as a source of income and as influencing Tamandaré's coral reefs with environmental education and other activities surrounding the Giant Grouper (Epinephelus itajara) (Note that there are some persons who are affiliated with the universities and are also active in the NGO Meros do Brasil and/or the NGO IRCOS (Instituto Recifes Costeiros)).

With three grains, tourism operators saw the Toyota Foundation as the most influential civil society entity as the (perceived) major funder of marine management programs and projects.

As a participant of the Tamandaré tourism operator net-map group, the Nauticá Ambiental Cooperative self-identified as providing services relating to the management of the Tamandaré closed reef area ('area fechada') and in sustainable small-scale marine transportation for tourists (using 'Jangadas'). They also stated to be helping to formulate reef-related regulations and to be supporting information exchange and implementation support for marine management (e.g., maintenance of marker buoys, participation in reef monitoring) in the wider CC-EPA area. Tourism operators saw the Fishing Colony ('Colonia Z-5') as providing for the social security of fisherfolk including pensions, sickness and maternity benefits, and as local fishers' political representative, but as of limited influence on local reef governance (1 grain in Figure 2). The Tamandaré fishers' group did not mention their fishing colony as affecting the local reef area.

The Tamandaré tourism operator net-map group saw the Jangada Operators Association and the Tourism Speedboat Cooperative ('Associação de lanchas') as supporting fishers in projects, such as obtaining nets and boats, and as promoting tourism activities. With only one grain for each, however, tourism operators saw these associations to have little influence on reef governance.

Tourism operators saw the two councils APA Guadelupe (a consultative integrated environmental protection area with marine and terrestrial territory) and COMDEMA (Tamandaré's deliberative municipal council) as with responsibilities and potentials for influencing the marine governance system without really fulfilling them. Tourism operators saw both the APA Guadalupe and its council and the COMDEMA as unconnected to other governance actors and of no influence on the Tamandare coral reef area (zero grains) (This view is disputed by a variety of other actors, including those involved in the respective councils). 


\section{Maragogi Net-Maps (Figure 2c, d in Main Text)}

The two Maragogi net-map groups had five fishermen and three tourism operators respectively, and identified 24 governance stakeholders from the private sector, government, and civil society for the Maragogi reef areas. As private sector ecosystem users, both net-map groups identified three types of boats taking tourists to the reefs: tourism speed boat operators ('lanchas') with six persons per vessel, 27 tourism catamaran operators with 54 persons per vessel, and operators of converted fishing boats for tourism ('escuna/barco adaptado', with a 12-person carrying capacity.

Both net-map groups indicated that all vessel operators have to pay a fee to the municipal government, which is meant to be used for enforcing the rules in the tourism zones. Since boat operators are responsible for tourist compliance with behavioural rules in the reef areas, they were seen to affect the sustainability of marine ecosystem use (Tourist boat operators were not available to join the net-mapping groups in Maragogi.). Tourism operators identified two additional reef tourism services offered by separate operators: diving and underwater photography. The users of these services and the service providers travelled to the natural pools in the above-mentioned tourism boats. Dive operators in the natural pools of Maragogi were attributed moderate influence (two grains) since they must assure safe operation and that tourists comply with rules (i.e., do not break or collect corals).

Photographers in the natural pools of Maragogi received only one grain. The tourism operators group also emphasized that. Owners of reception areas that distribute tourists to the boats hold a central position of power in Maragogi reef management. Reception owners also own most Maragogi catamarans and most receptions were also linked to beach front restaurants. The tourism net-map group attributed the maximum of four grains to reception owners since they channel the tourists, and thus, can influence the implementation of reef management rules, such as the limitations on the number of tourists on the reef.

Both Maragogi net-map groups emphasized that Tourists greatly influence marine ecosystem use in Maragogi (four grains), since they fuel the local economy and shape the municipality's marine governance system. The Maragogi tourism operator group felt that reef use was mainly driven by tourist demand. Fishing was also seen as important in Maragogi. While the tourism operators only saw fishers linked to their fishing colony, the fisher net-map group distinguished two types of fishers: vessel fishers engaged in seasonal open water fishing trips for finfish (8-9 days) and territorial fishing around and beyond the reef areas during winter/wet season, mainly for shrimp and lobster in medium-sized motorized vessels; and jangada fishers, engaged in artisanal fishing from small 'jangada' boats in the so-called "inner sea" between the coast and the coral reef area (Figure 1 in main article right hand inserts). The jangada fishers mostly own their small boats, and consume their catch or sell directly to restaurants and neighbours. The number of 'jangadeiros' in Maragogi was reported to have fallen sharply in recent years. Both net-map groups considered the influence of fishers on reef governance as moderate (two grains in Figure 2), and thought that the tourism industry in Maragogi did not improve fishers' incomes.

Maragogi net-map groups identified a total of five government organizations from different administrative levels as holding regulatory and rule enforcement responsibilities. The national government departments ICMBio, the Port Authority (Marinha do Brasil/Capitanía do Porto), and IBAMA were attributed the same responsibilities as in Tamandaré. Both net-map groups described the Port Authority as highly influential (four grains) by effectively registering boats and vessels and enforcing safety requirements on fishing and tourism boats in the area. The fisher group stated that the Port Authority also provided valuable information and capacity-building events.

Both Maragogi groups stated that IBAMA is responsible for enforcing fishery rules and marine resource monitoring, but felt it to be ineffective and hardly visiting the area (zero grains). In contrast, both groups saw ICMBio as very influential (four grains) in the marine governance system in Maragogi, due to their rule-setting and enforcement role. Both groups perceived that while ICMBio is officially mandated by the CC-EPA regulations to enforce the rules related to the tourism zones in the reefs, this control of tourism activities was actually delegated to the town government. Both groups expressed 
concern that this was not working well (e.g., that tourism operators exceeded the tourist numbers allowed in the reefs, or allowed the collection of coral fragments as souvenirs).

The Maragogi fisher net-map group saw the town government as without influence (zero grains) on organizing and enforcing reef area tourism regulations. The tourism operators' group perceived the same problem but regarded the town government (four grains) as a strongly negative influence in reef area governance. Therefore, the tourism net-map group marked a (black) obstruction arrow from the town government to ICMBio with respect to enforcing the rules and regulations of the tourism zones established under the CC-EPA (Figure 2). Both net-map groups saw very little de facto regulatory influence on tourism operations in the Maragogi reef area.

The two net-map groups identified seven civil society actors in Maragogi reef area governance. The fishing colony was seen by both groups as providing for social security needs, pensions, sickness and maternity benefits, and as the political representative and mediator of fishers (four grains in Figure 2).

The Association of Catamaran Operators and the Association of Speedboat Operators were listed by both net-map groups, but level of organization and collaboration within both associations were perceived as very low; the associations were even described as "paper organizations" by the tourism net-map group.

The tourism net-map group identified two NGOs in Maragogi coral reef governance: the Brazilian Toyota Foundation and a recently founded local NGO, the Instituto Agua e Terra. Both were considered as having remained without activity or impact by Maragogi's tourism net-mappers, and neither was mentioned by the Maragogi fishers' net-map group.

\section{References}

1. Biermann, F.; Betsill, M.M.; Viera, S.C.; Grupta, J.; Kanie, N.; Lebel, L.; Liverman, D.; Schroeder, H.; Siebenhüner, B.; Yanda, P.Z.; et al. Navigating the Anthropocene: The Earth System Governance Project Strategy Paper. Curr. Opin. Environ. Sustain. 2010, 2, 202-208. [CrossRef]

2. Alexander, S.M.; Armitage, D. A social relational network perspective for MPA science. Conserv. Lett. 2015, 8, 1-13. [CrossRef]

3. Olsen, S.B.; Page, G.G.; Ochoa, E. The Analysis of Governance Responses to Ecosystem Change: A Handbook for Assembling a Baseline; GKSS Research Centre: Geesthacht, Germany, 2009.

4. Brewer, T.D.; Moon, K. Towards a functional typology of small-scale fisheries co-management informed by stakeholder perceptions: A coral reef case study. Mar. Policy 2015, 51, 48-56. [CrossRef]

5. Christie, P. Marine Protected Areas as Biological Successes and Social Failures in Southeast Asia. Am. Fish. Soc. Symp. 2004, 42, 155-164.

6. Cicin-Sain, B.; Belfiore, S. Linking marine protected areas to integrated coastal and ocean management: A review of theory and practice. Ocean Coast. Manag. 2005, 48, 847-868. [CrossRef]

7. Bodin, Ö.; Crona, B.I. The role of social networks in natural resource governance: What relational patterns make a difference? Glob. Environ. Chang. 2009, 19, 366-374. [CrossRef]

8. Steiner, A. Democracy and Participation. In Global Sustainability-A Noble Cause; Schellnhuber, H.J., Molina, M., Stern, N., Huber, V., Kadner, S., Eds.; Cambridge University Press: Cambridge, UK, 2010.

9. Cárcamo, P.F. Collaboration and knowledge networks in coastal resources management: How critical stakeholders interact for multiple-use marine protected area implementation. Ocean Coast. Manag. 2014, 91, 5-16. [CrossRef]

10. Ferreira, B.P.; Maida, M. Monitoring Brazilian Coral Reefs, Status and Perspectives; Brasilia, Brazil, 2006.

11. Prates, A.P.L.; Gonçalves, M.A.; Rosa, M.R. Panorama da Conservação dos Ecossistemas Costeiros e Marinhos no Brasil, 2nd ed.; Ministério do Meio Ambiente (MMA): Brasilia, Brazil, 2012; ISBN 9788577381425.

12. Ferreira, B.P.; Maida, M. Characteristics and Perspectives for Fishery Management in the Coral Coast Marine Protected Area. In Aquatic Protected Areas as Fisheries Management Tools, Protected Areas of Brazil Series; Brazilian Institute of the Environment and Renewable Natural Resources (IBAMA): Brasilia, Brazil, 2007; pp. 39-50. 
13. Puppim de Oliveira, J.A. Governmental responses to tourism development: Three Brazilian case studies. Tour. Manag. 2003, 24, 97-110. [CrossRef]

14. Gasalla, M.A. Do all answers lie within (the community)? Fishing rights and marine conservation. In World Small-Scale Fisheries: Contemporary Visions; Chuenpagdee, R., Ed.; Eburon Acdemic Publisher: Delft, The Netherlands, 2011; pp. 185-203.

15. Gerhardinger, L.C.; Gorris, P.; Gonçalves, L.R.; Herbst, D.F.; Vila-Nova, D.A.; de Carvalho, F.G.; Glaser, M.; Zondervan, R.; Glavovic, B. Healing Brazil's Blue Amazon: The role of knowledge networks in nurturing cross-scale transformations at the frontlines of ocean sustainability. Front. Mar. Sci. Mar. Affairs Policy 2018, 4 , 395. [CrossRef]

16. Juffe-Bignoli, D.; Burgess, N.D.; Bingham, H.; Belle, E.M.S.; de Lima, M.G.; Deguignet, M.; Bertzky, B.; Milam, A.N.; Martinez-Lopez, J.; Lewis, E.; et al. Protected Planet Report 2014. Tracking Progress towards Global Targets for Protected Areas; UNEP World Conservation Monitoring Centre: Cambridge, UK, 2014.

17. Jones, P.J.S. Governing Marine Protected Areas: Resilience through Diversity; Routledge: Oxon, UK; New York, NY, USA, 2014.

18. Wever, L.; Glaser, M.; Gorris, P.; Ferrol-Schulte, D. Decentralization and participation in integrated coastal management: Policy lessons from Brazil and Indonesia. Ocean Coast. Manag. 2012, 66, 63-72. [CrossRef]

19. Roberts, C.M.; Bohnsack, J.A.; Gell, F.; Hawkins, J.P.; Goodridge, R. Effects of marine reserves on adjacent fisheries. Science 2001, 294, 1920-1923. [CrossRef] [PubMed]

20. Pomeroy, R.S.; Mascia, M.B.; Pollnac, R.B. Marine protected areas: The social dimension. In Report and Documentation of the Expert Workshop on Marine Protected Areas and Fisheries Management: Review and Issues of Consideration; Food and Agriculture Organisation (FAO), Ed.; FAO: Rome, Italy, 2007; pp. 149-182.

21. Rife, A.N.; Erisman, B.; Sanchez, A.; Octavio, A.-O. When good intentions are not enough. Insights on networks of "paper park" marine protected areas. Conserv. Lett. 2013, 6, 200-212. [CrossRef]

22. Fox, H.E.; Mascia, M.B.; Basurto, X.; Costa, A.; Glew, L.; Heinemann, D.; Karrer, L.B.; Lester, S.E.; Lombana, A.V.; Pomeroy, R.S.; et al. Reexamining the science of marine protected areas: Linking knowledge to action. Conserv. Lett. 2012, 5, 1-10. [CrossRef]

23. Walker-Springett, K.; Jefferson, R.; Böck, K.; Breckwoldt, A.; Comby, E.; Cottet, M.; Hübner, G.; Le Lay, Y.-F.; Shaw, S.; Wyles, K. Ways forward for aquatic conservation: Applications of environmental psychology to support management objectives. J. Environ. Manag. 2016, 166, 525-536. [CrossRef] [PubMed]

24. Karnad, D.; Ganga, M.; Karanth, K.K. Perceptions matter: How fishermen's perceptions affect trends of sustainability in Indian fisheries. Oryx 2013, 48, 218-227. [CrossRef]

25. Hicks, C.C.; Cinner, J.E. Social, institutional, and knowledge mechanisms mediate diverse ecosystem service benefits from coral reefs. Proc. Natl. Acad. Sci. USA 2014, 111, 17791-17796. [CrossRef] [PubMed]

26. Katikiro, R.; Ashoka Deepananda, K.H.M.; Macusi, E. Interplay between perceived changes in fishery and social structures in Tanzanian coastal fishing communities. Fish. Res. 2015, 164, 249-253. [CrossRef]

27. Rogerson, J.J.M. Being heard: Thinking through different versions of rationality, epistemological policing and dissonances in marine conservation. Mar. Policy 2015, 60, 325-330. [CrossRef]

28. Bennett, N.J. Using perceptions as evidence to improve conservation and environmental management. Conserv. Biol. 2016, 30, 582-592. [CrossRef] [PubMed]

29. Beyerl, K.; Putz, O.; Breckwoldt, A. The Role of Perceptions for Community-Based Marine Resource Management. Front. Mar. Sci. 2016, 3, 238. [CrossRef]

30. Gelcich, S.; O'Keeffe, J. Emerging frontiers in perceptions research for aquatic conservation. Aquat. Conserv. Mar. Freshw. Ecosyst. 2016, 26, 986-994. [CrossRef]

31. Schiffer, E.; Hauck, J. Net-Map: Collecting Social Network Data and Facilitating Network Learning through Participatory Influence Network Mapping. Field Methods 2010, 22, 231-249. [CrossRef]

32. Dantas, E.W.C. Metropolização turística em região monocultora industrializada. Mercator 2013, 12 , 65-84. [CrossRef]

33. IOC/UNESCO; IMO; FAO; UNDP. A Blueprint for Ocean and Coastal Sustainability; IOC/UNESCO: Paris, France, 2011.

34. Sell-Greiser, C. Tourismus und Naturschutz: Partizipation zur Konfliktvermeidung im integrierten Küstenzonenmanagement. In Küste, Ökologie und Mensch; Glaeser, B., Ed.; Oekom: München, Germany, 2005; pp. 203-218. 
35. Macedo, H.S.; Vivacqua, M.; Rodrigues, H.C.L.; Gerhardinger, L.C. Governing wide coastal-marine protected territories: A governance analysis of the Baleia Franca Environmental Protection Area in South Brazil. Mar. Policy 2013, 41, 118-125. [CrossRef]

36. ICMBio. Plano de Manejo da Área de Proteção Ambiental Costa dos Corais; ICMBio: Tamandaré, Brazil, 2013.

37. Gorris, P. Entangled? Linking Governance Systems for Regional-Scale Coral Reef Management: Analysis of Case Studies in Brazil and Indonesia; Jacobs University: Bremen, Germany, 2015.

38. Prefeitura Tamandaré Dados Geográficos. Available online: http://www.tamandare.pe.gov.br/?pag= munic_geog (accessed on 27 September 2016).

39. Leão, Z.M.A.N.; Kikuchi, R.K.P.; Ferreira, B.P.; Neves, E.G.; Sovierzosky, H.H.; Oliveira, M.D.M.; Maida, M.; Correia, M.D.; Johnsson, R. Brazilian coral reefs in a period of global change: A synthesis. Braz. J. Oceanogr. 2016, 64, 97-116. [CrossRef]

40. Bastian, M.; Heymann, S.; Jacomy, M. Gephi: An open source software for exploring and manipulating networks. In Proceedings of the International AAAI Conference on Weblogs and Social Media, San Jose, CA, USA, 17-20 May 2009.

41. Bernard, R.H. Research Methods in Anthropology: Qualitative and Quantitative Approaches, 4th ed.; AltaMira Press: Oxford, UK, 2006.

42. Deutsche Forschungsgemeinschaft (DFG). Sicherung Guter Wissenschaftlicher Praxis: Empfehlungen der Kommission "Selbstkontrolle in der Wissenschaft"; Wiley-VCH Verlag GmbH \& Co. KGaA: Weinheim, Germany, 2013; ISBN 9783527337033.

43. Clayton, S.; Myers, G. Conservation Psychology: Understanding and Promoting Human Care for Nature; Wiley-Blackwell: West Sussex, UK, 2009.

44. Gallagher, S.; Zahavi, D. The Phenomenological Mind, 2nd ed.; Routledge: Oxon, UK; New York, NY, USA, 2012.

45. Steg, L.; van den Berg, A.E.; de Groot, J.I.M. Environmental psychology: History, scope and methods. In Environmental Psychology; Steg, L., van den Berg, A.E., de Groot, J.I.M., Eds.; Wiley-Blackwell: Oxford, UK, 2013; pp. 1-12.

46. Gerrig, R.J.; Zimbardo, P.G. Psychology and Life, 18th ed.; Allyn and Bacon: Boston, MA, USA, 2008.

47. McClanahan, T.R.; Maina, J.; Davies, J. Perceptions of resource users and managers toweards fisheries management options in Kenyan coral reefs. Fish. Manag. Ecol. 2005, 12, 105-112. [CrossRef]

48. Jefferson, R.; McKinley, E.; Capstick, S.; Fletcher, S.; Griffin, H.; Milanese, M. Understanding audiences: Making public perceptions research matter to marine conservation. Ocean Coast. Manag. 2015, 115, 61-70. [CrossRef]

49. Grothmann, T.; Patt, A. Adaptive Capacity and Human Cognition: The Process of Individual Adaptation to Climate Change. Glob. Environ. Chang. 2005, 15, 199-213. [CrossRef]

50. Vodden, K.; Bannister, K. Circularizing Knowledge Flows: Institutional Structures, Policies, and Practices for Community-University Collaborations. In Making and Moving Knowledge: Interdisciplinary and Community-Based Research in a World on the Edge; Sutton Lutz, J., Neis, B., Eds.; McGill-Queen's University Press: Montreal, QC, Canada; Kingston, ON, Canada; London, UK; Ithaca, NY, USA, 2008; pp. 245-270.

51. Pomeroy, R.S.; Berkes, F. Two to tango: The role of government in fisheries co-management. Mar. Policy 1997, 21, 465-480. [CrossRef]

52. Berghöfer, A.; Wittmer, H.; Rauschmayer, F. Stakeholder participation in ecosystem-based approaches to fisheries management: A synthesis from European research projects. Mar. Policy 2008, 32, 243-253. [CrossRef]

53. Gerhardinger, L.C.; Godoy, E.A.; Jones, P.J.S. Local ecological knowledge and the management of marine protected areas in Brazil. Ocean Coast. Manag. 2009, 52, 154-165. [CrossRef]

54. Stein, C.; Ernstson, H.; Barron, J. A social network approach to analyzing water governance: The case of the Mkindo catchment, Tanzania. Phys. Chem. Earth 2011, 36, 1085-1092. [CrossRef]

55. Hauck, J.; Stein, C.; Schiffer, E.; Vandewalle, M. Seeing the forest and the trees: Facilitating participatory network planning in environmental governance. Glob. Environ. Chang. 2015, 35, 400-410. [CrossRef]

56. Gorris, P. Deconstructing the Reality of Community-Based Management of Marine Resources in a Small Island Context in Indonesia. Front. Mar. Sci. 2016, 3, 120. [CrossRef]

57. Ferreira, B.P.; Messias, L.T.; Maida, M. The Environmental Municipal Councils as an Instrument in Coastal Integrated Management: The Área de Proteção Ambiental Costa dos Corais (AL/PE) Experience. J. Coast. Res. 2006, 39, 1003-1007. 
58. Turner, R.A.; Forster, J.; Fitzsimmons, C.; Gill, D.; Mahon, R.; Peterson, A.; Stead, S. Social fit of coral reef governance varies among individuals. Conserv. Lett. 2017, e12422. [CrossRef]

59. Gerhardinger, L.C.; Godoy, E.A.; Jones, P.J.S.; Sales, G.; Ferreira, B.P. Marine protected dramas: The flaws of the Brazilian National System of Marine Protected Areas. Environ. Manag. 2011, 47, 630-643. [CrossRef] [PubMed]

60. Adger, W.N.; Brown, K.; Tompkins, E.L. The Political Economy of Cross-Scale Networks in Resource Co-Management. Ecol. Soc. 2006, 10, 9. [CrossRef]

61. Alexander, S.M.; Andrachuk, M.; Armitage, D. Navigating governance networks for community-based conservation. Front. Ecol. Environ. 2016, 14, 155-164. [CrossRef]

62. Alexander, S.M.; Epstein, G.; Bodin, Ö.; Armitage, D.R.; Campbell, D. Participation in planning and social networks increase social monitoring in community-based conservation. Conserv. Lett. 2018, in press. [CrossRef]

63. Bodin, Ö. Collaborative environmental governance: Achieving collective action in social-ecological systems. Science 2017, 357. [CrossRef] [PubMed]

64. Figuereido, M. Promotion and Management in Marine Fisheries in Brazil. In Towards Sustainable Fisheries Law. A Comparative Analysis; Winter, G., Ed.; International Union for Conservation of Nature (IUCN): Gland, Switzerland, 2009; pp. 187-232.

65. Diegues, A.C. Marine Protected Areas and Artisanal Fisheries in Brazil; International Collective in Support of Fishworkers (Samudra Monograph): Chennai, India, 2008.

(C) 2018 by the authors. Licensee MDPI, Basel, Switzerland. This article is an open access article distributed under the terms and conditions of the Creative Commons Attribution (CC BY) license (http://creativecommons.org/licenses/by/4.0/). 